\title{
Structural Characterization of Two Modifications of Tris(tetrahydrofuran)(tris(trimethylsilyl)silyl)lithium: A Compound with a ${ }^{29} \mathrm{Si}-{ }^{7} \mathbf{L i}$ NMR Coupling
}

\author{
Andreas Heine, Regine Herbst-Irmer, George M. Sheldrick, and Dietmar Stalke \\ Institut für Anorganische Chemie der Universität Göttingen, Tammannstrasse 4, \\ W-3400 Göttingen, Germany
}

Received September 17, 1992

\begin{abstract}
The crystal structures of $\left(\mathrm{Me}_{3} \mathrm{Si}\right)_{4} \mathrm{Si} \cdot \mathrm{THF}(a=b=12.310$ (1) $\AA, c=17.308(2) \AA$, tetragonal, space group $P 4 / n c c$ (No. 130), $Z=4),\left[\left(\mathrm{Me}_{3} \mathrm{Si}\right)_{4} \mathrm{Si}\right]\left[\left(\mathrm{Me}_{3} \mathrm{Si}\right)_{3} \mathrm{SiLi}(\mathrm{THF})_{3}\right]_{2}(a=b=15.146(8) \AA, c=21.338(10) \AA$, trigonal, space group $P \overline{3} c 1$ (No. 165), $Z=2$ ), $\left(\mathrm{Me}_{3} \mathrm{Si}\right)_{3} \mathrm{SiLi}(\mathrm{THF})_{3}(a=b=31.342(4) \AA, c=22.000(6) \AA$, rhombohedral, space group $R 3 c$ (No. 161), $Z=24)$, and $\left(\mathrm{Me}_{3} \mathrm{Si}\right)_{3} \mathrm{SiSi}\left(\mathrm{SiMe}_{3}\right)_{3}$. THF $(a=11.360(3) \AA, b=17.131(6) \AA, c=18.952(6)$ $\AA, \beta=91.21(3)^{\circ}$, monoclinic, space group $P 2_{1} / c$ (No. 14), $Z=4$ ), have been determined by low-temperature $X$-ray analysis. Whereas the small Si-Si-Si angle in (tris(trimethylsilyl)silyl) lithium of $102.1^{\circ}$ supports the ionic character of the $\mathrm{Si}-\mathrm{Li}$ bond, there must be at least some covalent contribution leading to a ${ }^{1} J\left[{ }^{29} \mathrm{Si},{ }^{7} \mathrm{Li}\right]$ coupling constant of $38.6 \mathrm{~Hz}$. A modified preparation for $\left(\mathrm{Me}_{3} \mathrm{Si}\right)_{3} \mathrm{SiLi}(\mathrm{THF})_{3}$ is reported giving the pure product rather than the cocrystallization product $\left[\left(\mathrm{Me}_{3} \mathrm{Si}\right)_{4} \mathrm{Si}\right]\left[\left(\mathrm{Me}_{3} \mathrm{Si}\right)_{3} \mathrm{SiLi}(\mathrm{THF})_{3}\right]_{2}$, where the starting material is still present in the ratio 1:2. The pure product is far more reactive than the cocrystallized material and is as pyrophoric as ' $\mathrm{BuLi}$ powder.
\end{abstract}

\section{Introduction}

(Tris(trimethylsilyl)silyl)lithium is a versatile reagent for the synthesis of a great variety of polysilyl derivatives. This precursor is stable and dissolves well even in nonpolar hydrocarbons when coordinated with THF (tetrahydrofuran) first. Since the development of this ligand by Gilman and Smith, 1,2 it has been used widely in both transition metal chemistry ${ }^{3-5}$ and main group chemistry. ${ }^{5-8}$ The high steric requirements, along with the good solubility of the products in hydrocarbons and the electronreleasing properties of $-\mathrm{Si}\left(\mathrm{SiMe}_{3}\right)_{3}$, make it a very useful ligand. The original 1968 recipe for $\left(\mathrm{Me}_{3} \mathrm{Si}\right)_{3} \mathrm{SiLi}(\mathrm{THF})_{3}$ of Gilman and Smith $^{2}$ has been modified and optimized by Gutekunst and Brook ${ }^{9}$ in 1982, resulting in a cleaner reaction and higher yield. From the integrated NMR signals it was shown that the compound contains three molecules of THF per $\mathrm{Li}$, but no crystal structure data were available. We report in this paper the crystal structures of $\left(\mathrm{Me}_{3} \mathrm{Si}\right)_{4} \mathrm{Si}$ (1), [( $\left.\left(\mathrm{Me}_{3} \mathrm{Si}\right)_{4} \mathrm{Si}\right]\left[\left(\mathrm{Me}_{3} \mathrm{Si}\right)_{3} \mathrm{SiLi}(\mathrm{THF})_{3}\right]_{2}$ (2), $\left(\mathrm{Me}_{3} \mathrm{Si}\right)_{3} \mathrm{SiLi}(\mathrm{THF})_{3}(3)$, and $\left(\mathrm{Me}_{3} \mathrm{Si}\right)_{3} \mathrm{SiSi}\left(\mathrm{SiMe}_{3}\right)_{3}$ (4). The ${ }^{1} J[\mathrm{Si}, \mathrm{Li}]$ coupling (observed in both the ${ }^{29} \mathrm{Si}$ and ${ }^{7} \mathrm{Li} \mathrm{NMR}$ spectra) shows that the $\mathrm{Si}-\mathrm{Li}$ bond in $\mathbf{3}$ is retained in solution.

\section{Results and Discussion}

Preparation of 1-4. Compound 1 was prepared in good yield (69\%) by the literature method. ${ }^{1} 2$ and 3 were prepared according to eqs 1 and 2, respectively. For the preparation, we employed the published procedure 9 with the minor modification of using the pure methyllithium rather than the methyllithium-lithium bromide complex. It can be seen clearly from eq 1 that the lithiation has not come to completion after $24 \mathrm{~h}$, as 1 equiv of the

(1) Gilman, H.; Smith, C. L. J. Organomet. Chem. 1967, 8, 245

(2) Gilman, H.; Smith, C. L. J. Organomet. Chem. 1968, 14, 91 .

(3) Arnold, J.; Tilley, T. D.; Rheingold, A. L.; Geib, S. J. Inorg. Chem. 1987, 26, 2106.

(4) Meyer, J.; Willnecker, J.; Schubert, U, Chem, Ber, 1989, 122, 223.

(5) Piana, H.; Wagner, H.; Schubert, U. Chem. Ber. 1991, 124, 63.

(6) Arif, A. M.; Cowley, A. H.; Elkins, T. M. J. Organomet. Chem. 1987, 325, C11.

(7) Mallela, S. P.; Geanangel, R. A. Inorg. Chem. 1990, 29, 3525

(8) Arif, A. M.; Cowley, A. H.; Elkins, T. M.; Jones, R. A. J. Chem. Soc., Chem. Commun. 1986, 1776.

(9) Gutekunst, G.; Brook, A. G. J. Organomet. Chem. 1982, 225, 13

$$
\begin{aligned}
& 3 \mathrm{Si}\left(\mathrm{SiMe}_{3}\right)_{4}+2 \mathrm{MeLi} \underset{1-\mathrm{d} \text { stirring }}{\stackrel{\mathrm{THF}}{\rightarrow}}
\end{aligned}
$$

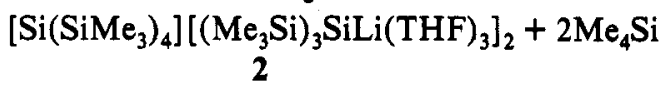

$$
\begin{aligned}
& \mathrm{Si}\left(\mathrm{SiMe}_{3}\right)_{4}+\mathrm{MeLi} \underset{4-\mathrm{d} \text { stirring }}{\stackrel{\mathrm{THF}}{\rightarrow}} \\
& \left(\mathrm{Me}_{3} \mathrm{Si}\right)_{3} \mathrm{SiLi}(\mathrm{THF})_{3}+\mathrm{Me}_{4} \mathrm{Si} \\
& 3
\end{aligned}
$$

tetrakis(trimethylsilyl)silane starting material cocrystallizes with 2 equiv of the (tris(trimethylsilyl)silyl)lithium product. After the reaction mixture is stirred for $4 \mathrm{~d}$ at room temperature, the metalation reaction is completed and pure product is obtained according to eq 2.103 is oxidatively coupled by lead dichloride, leading to 4 rather than the expected $\mathrm{Pb}\left[\mathrm{Si}\left(\mathrm{SiMe}_{3}\right)_{3}\right]_{2}$

$$
\begin{aligned}
\mathrm{PbCl}_{2}+2\left(\mathrm{Me}_{3} \mathrm{Si}\right)_{3} \mathrm{SiLi}(\mathrm{THF})_{3} \underset{\text { toluene }}{-78^{\circ} \mathrm{C}} \\
\left(\mathrm{Me}_{3} \mathrm{Si}\right)_{3} \mathrm{SiSi}\left(\mathrm{SiMe}_{3}\right)_{3}+2 \mathrm{LiCl}+\mathrm{Pb}
\end{aligned}
$$

During the preparation of this publication, we learned of a recent report by Geanangel et al. ${ }^{11}$ which describes a similar synthesis of 4.

Crystal Structure of 1. The molecule of tetrakis(trimethylsilyl)silane adopts approximate $T_{d}$ symmetry (Figure 1), and the basic structural dimensions in the solid state are in good agreement with the electron diffraction study of the molecule ${ }^{13}$ (Table I). The $\mathrm{SiMe}_{3}$ groups are staggered as in a molecular gear-wheel, and the whole molecule appears as an almost ideal sphere with an outer shell of hydrogen atoms, followed by a layer of carbon

(10) Biffar, W;; Nöth, H. Z. Naturforsch. 1981, 36B, 1509.

(11) Mallela, S. P.; Bernal, I.; Geanangel, R. A. Inorg. Chem. 1992, 31 , 1626.

(12) Bock, H.; Ruppert, K.; Nâther, C.; Havlas, Z.; Herrmann, H. F.; Arad, C.; Göbel, I.; John, A.; Meuret, J.; Nick, S.; Rauschenbach, A.; Seitz, W.; Vaupel, T.; Solouki, B. Angew. Chem. 1992, 104, 564; Angew. Chem., Int. Ed. Engl. 1992, 31, 550.

(13) Bartell, L. S.; Clippard, F. B., Jr.; Boates, T. L. Inorg. Chem. 1970, 9 , 2436.

(C) 1993 American Chemical Society 
Table I. Selected Bond Lengths ( $\AA$ ) and Angles (deg) for 1-4

\begin{tabular}{|c|c|c|c|c|c|}
\hline compound & av $\mathrm{Si}-\mathrm{C}$ & av $\mathrm{Si}-\mathrm{Si}$ & av $\mathrm{Si}-\mathrm{Li}$ & av $\mathrm{Si}-\mathrm{Si}-\mathrm{Si}$ & av $\mathrm{Si}-\mathrm{Si}-\mathrm{Li}$ \\
\hline $\begin{array}{l}\left(\mathrm{Me}_{3} \mathrm{Si}\right)_{4} \mathrm{Si}(1)^{a} \\
\left.(\mathrm{Me})_{3} \mathrm{Si}\right)_{4} \mathrm{Si} \mathrm{in} 2 \\
\left(\mathrm{Me} e_{3} \mathrm{Si}\right)_{3} \mathrm{SiLi}(\mathrm{THF})_{3} \text { in } 2^{b} \\
\left.(\mathrm{Me})_{3} \mathrm{Si}\right)_{3} \mathrm{SiLi}(\mathrm{THF})_{3}(3)^{c} \\
\left(\mathrm{Me}_{3} \mathrm{Si}\right)_{3} \mathrm{SiSi}\left(\mathrm{SiMe}_{3}\right)_{3}(4)\end{array}$ & $\begin{array}{l}1.879(4) \\
1.878(10) \\
1.888(5) \\
1.888(7) \\
1.875(3)\end{array}$ & $\begin{array}{l}2.346(1) \\
2.334(4) \\
2.334(3) \\
2.330(2) \\
2.373(2)^{d} \\
2.390(2)\end{array}$ & $\begin{array}{l}2.674(13) \\
2.644(12)\end{array}$ & $\begin{array}{l}109.5(1) \\
109.5(2) \\
101.8(1) \\
102.4(1) \\
104.8(1)^{e} \\
113.8(1)^{f}\end{array}$ & $\begin{array}{l}116.4(1) \\
115.8(2)\end{array}$ \\
\hline
\end{tabular}

${ }^{a}$ Crystallographic $D_{2}$ symmetry. ${ }^{b}$ Crystallographic $C_{3}$ symmetry. ${ }^{c}$ Two independent molecules, one of which has crystallographic $C_{3}$ symmetry. d Only the Si-Si distances of the trimethylsilyl groups at the periphery of the molecule have been averaged; the second value is the length of the central $\mathrm{Si}(1)-\mathrm{Si}(5)$ bond. ${ }^{e}$ Average $\mathrm{Me}_{3} \mathrm{Si}-\mathrm{Si}-\mathrm{SiMe}_{3}{ }^{f}$ Average $\mathrm{Me}_{3} \mathrm{Si}-\mathrm{Si}-\mathrm{Si}\left(\mathrm{SiMe}_{3}\right)_{3}$.

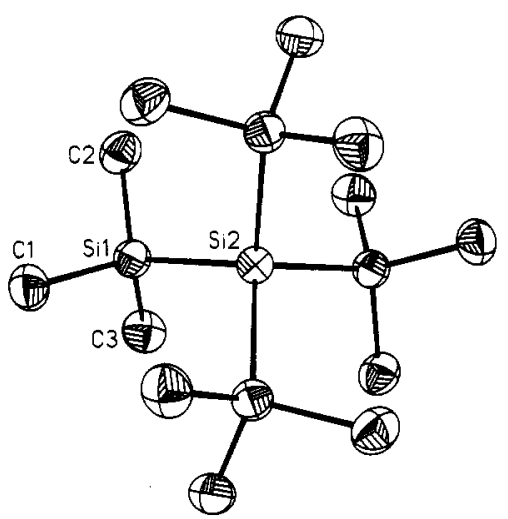

Figure 1. Structure of $\left(\mathrm{Me}_{3} \mathrm{Si}\right)_{4} \mathrm{Si}(\mathrm{1})$ in the solid state. The uncoordinated THF molecule is omitted.

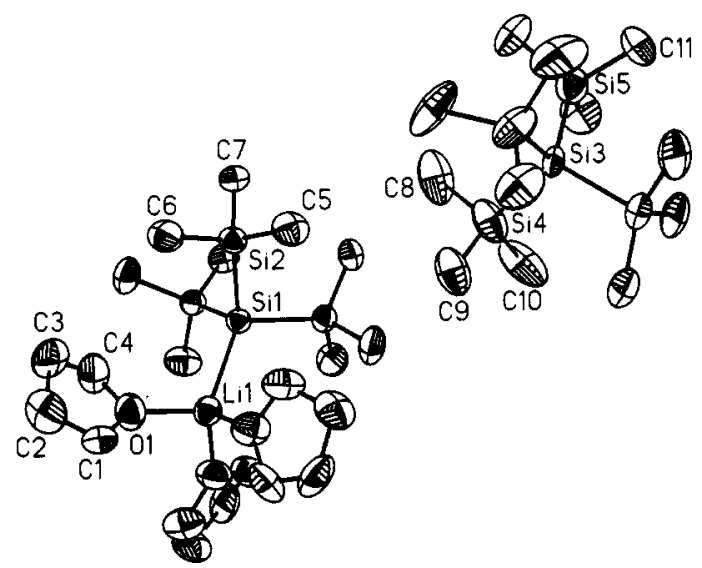

Figure 2. Structure of $\left[\left(\mathrm{Me}_{3} \mathrm{Si}\right)_{4} \mathrm{Si}\right]\left[\left(\mathrm{Me}_{3} \mathrm{Si}\right)_{3} \mathrm{SiLi}(\mathrm{THF})_{3}\right]_{2}(2)$ in the solid state.

atoms and a core of silicon atoms. The Si-Si bond of 2.346(1) $\AA$ and the average $\mathrm{Si}-\mathrm{C}$ bond of $1.879(4) \AA$ are slightly shorter than those in the gas phase (2.361(3) and $1.889(3) \AA){ }^{13} \mathrm{~A}$ librational correction increased the Si-Si distances by $0.004 \AA$ and $\mathrm{Si}-\mathrm{C}$ by about $0.003 \AA$.

Crystal Structures of 2 and 3. In 2, 1 equiv of tetrakis(trimethylsilyl)silane cocrystallizes with 2 equiv of (tris(trimethylsilyl)silyl)lithium (Figure 2). The structures of the two components of 2 are almost identical to those of the same compounds crystallized independently as 1 and 3 . The lithiation has almost no influence on the $\mathrm{Si}-\mathrm{C}$ and the $\mathrm{Si}-\mathrm{Si}$ bond lengths (Table I). The average $\mathrm{Si}-\mathrm{Li}$ bond length of $2.66 \AA$ is consistent with the three other $\mathrm{Si}-\mathrm{Li}$ bonds reported for molecular structures $(2.63$ $\AA$ in $\left(\mathrm{Me}{ }_{3} \mathrm{Si}\right)_{3} \mathrm{SiLi} \cdot 1.5 \mathrm{DME},{ }^{14} \mathrm{DME}=\mathrm{MeOCH}_{2} \mathrm{CH}_{2} \mathrm{OMe} ; 2.70$ $\AA$ in $\mathrm{Me}_{3} \mathrm{SiLi} \cdot 1.5 \mathrm{TMEDA},{ }^{15} \mathrm{TMEDA}=\mathrm{Me}_{2} \mathrm{NCH}_{2} \mathrm{CH}_{2} \mathrm{NMe}_{2}$; $2.65 \AA$ in $\left.\left[\mathrm{Me}_{3} \mathrm{SiLi}\right]_{6}\right) .{ }^{16}$ The parameter most affected by

(14) Becker, G.; Hartmann, H.-M.; Münch, A.; Riffel, H. Z. Anorg. Allg. Chem. 1985, 530, 29.

(15) Tecle, B.; Ilsley, W. H.; Oliver, J. P. Organometallics 1982, 1, 875.

(16) Schaaf, T. F.; Glick, M. D.; Oliver, J. P.; Butler, W. J. Am. Chem. Soc. 1974, 96, 7593. Ilsley, W. H.; Schaaf, T. F.; Glick, M. D.; Oliver, J. P. J. Am. Chem. Soc. 1980, 102, 3769.

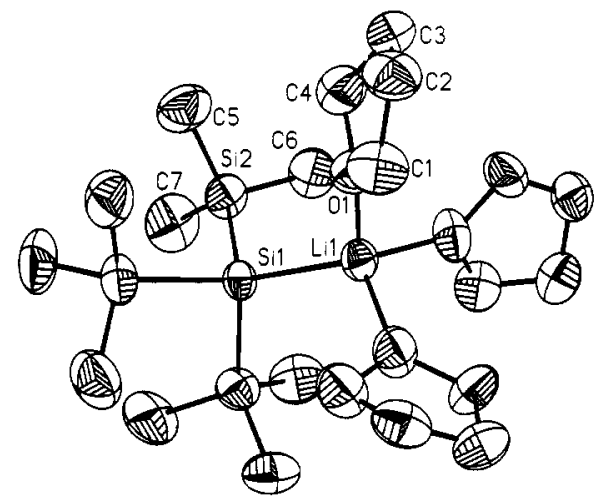

Figure 3. Structure of $\left(\mathrm{Me} \mathrm{S}_{3} \mathrm{Si}\right)_{3} \mathrm{SiLi}(\mathrm{THF})_{3}(3)$ in the solid state.

replacing a $\mathrm{SiMe}_{3}$ group with $\mathrm{Li}(\mathrm{THF})_{3}$ is the $\mathrm{Si}-\mathrm{Si}-\mathrm{Si}$ angle. It is reduced from the ideal tetrahedral value of $109.5^{\circ}$ in 1 to a mean value of $102.1^{\circ}$ in 2 and 3. The bulk of the $\mathrm{Li}(\mathrm{THF})_{3}$ group alone is not sufficient to account for this reduction, because in the even more sterically crowded $\left(\mathrm{Me}_{3} \mathrm{Si}\right)_{3} \mathrm{SiSi}\left(\mathrm{SiMe}_{3}\right)_{3}(4)$ the average $\mathrm{Me}_{3} \mathrm{Si}-\mathrm{Si}-\mathrm{SiMe}_{3}$ angle is reduced only to $104.8^{\circ}$ (Table I).

The nature of the Si-metal bond might have an influence on the $\mathrm{Si}-\mathrm{Si}-\mathrm{Si}$ angle of the ligand. The difference in electronegativity between silicon and lithium is about 0.9 , whereas it is 0.3 between (for example) silicon and aluminum and 0.0 between silicon and copper. That means that the bond between silicon and lithium is much more ionic than $\mathrm{Si}-\mathrm{Al}$ or $\mathrm{Si}-\mathrm{Cu}$ and is closer to the extreme description $\left(\mathrm{Me}_{3} \mathrm{Si}\right)_{3} \mathrm{Si}^{-}+\mathrm{Li}(\mathrm{THF})_{3}$. The Si-Si$\mathrm{Si}$ angles of $101.8^{\circ}$ in $2,102.4^{\circ}$ in 3 , and $104.0^{\circ}$ in $\left(\mathrm{Me}_{3} \mathrm{Si}\right)_{3}-$ SiLi-1.5DME 14 indicate that the lone pair in this resonance extreme is stereochemically active. The $\mathrm{Si}-\mathrm{Si}-\mathrm{Si}$ angles of $107.5^{\circ} 17$ in $\left(\mathrm{Me}_{3} \mathrm{Si}\right)_{3} \mathrm{SiAlPh}_{2}$ (THF) and $110.0^{\circ} 18$ in both $\left[\mathrm{Li}(\mathrm{THF})_{4}\right]\left[\mathrm{Cl}_{3} \mathrm{AlSi}\left(\mathrm{SiMe}_{3}\right)_{3}\right]$ and $\left[\mathrm{Li}(\mathrm{THF})_{4}\right]\left[\mathrm{Cu}_{5} \mathrm{Cl}_{4}(\mathrm{Si}-\right.$ $\left.\left.\left(\mathrm{SiMe}_{3}\right)_{3}\right\}_{2}\right]$ also show a correlation between $\mathrm{Si}-\mathrm{Si}-\mathrm{Si}$ angle and $\mathrm{M}-\mathrm{Si}$ electronegativity difference. This thesis is supported by the ${ }^{29} \mathrm{Si}$ NMR chemical shift of the central silicon atom. In 3 this shift is $-189.4 \mathrm{ppm}$ (Figure 4), in 4 it is $-130.04 \mathrm{ppm}$, and in $\left[\mathrm{Li}(\mathrm{THF})_{4}\right]\left[\mathrm{Cl}_{3} \mathrm{AlSi}\left(\mathrm{SiMe}_{3}\right)_{3}\right]^{18}$ it is $-115.66 \mathrm{ppm}$, indicating that the electron density at silicon decreases as the $\mathrm{Si}-\mathrm{Si}-\mathrm{Si}$ angle increases.

Crystals of 2 decompose rapidly and exothermally when exposed to air, ${ }^{9}$ but 3 is orders of magnitude more reactive. On exposure to air, it catches fire instantaneously, and it is comparable in reactivity to' $\mathrm{BuLi}$ powder. We are convinced that the accidental use of the cocrystallized material 2 instead of the pure material 3 is one of the reasons for the not very clean reactions which have been reported with (tris(trimethylsilyl)silyl)lithium. Both materials crystallize very well from pentane as white powders.

NMR Studies of 3. Although we pointed out earlier that the $\mathrm{Si}-\mathrm{Li}$ bond is polar, there must be a significant covalent contribution, since we observe a ${ }^{1} J\left[{ }^{29} \mathrm{Si},{ }^{7} \mathrm{Li}\right]$ NMR coupling in both the ${ }^{29} \mathrm{Si}$ and the ${ }^{7} \mathrm{Li} \mathrm{NMR}$ spectra (Figure 4 ). The

(17) Sierra, M. L.; de Mel, V. S. J.; Oliver, J. P. Organometallics 1989, 8, 2312.

(18) Heine, A.; Stalke, D. Angew. Chem. 1993, 105, 90; Angew. Chem., Int. Ed. Engl. 1993, 32, 121. 
Table II. Crystal Data for 1-4

\begin{tabular}{|c|c|c|c|c|}
\hline & 1 & 2 & 3 & 4 \\
\hline $\begin{array}{l}\text { formula } \\
\text { formula weight }\end{array}$ & $\begin{array}{l}\mathrm{C}_{12} \mathrm{H}_{36} \mathrm{Si}_{5}+\mathrm{C}_{4} \mathrm{H}_{8} \mathrm{O} \\
392.96\end{array}$ & $\begin{array}{l}\mathrm{C}_{54} \mathrm{H}_{138} \mathrm{Li}_{2} \mathrm{O}_{6} \mathrm{Si}_{13} \\
1262.69\end{array}$ & $\begin{array}{l}\mathrm{C}_{21} \mathrm{H}_{51} \mathrm{LiO}_{3} \mathrm{Si}_{4} \\
470.92\end{array}$ & $\begin{array}{l}\mathrm{C}_{18} \mathrm{H}_{54} \mathrm{Si}_{8}+\mathrm{C}_{4} \mathrm{H}_{8} \mathrm{O} \\
567.44\end{array}$ \\
\hline space group & $P 4 / n c c$ (No. 130) & $P \overline{3} c 1$ (No. 165$)$ & $R 3 c$ (No. 161) & $P_{21 / c}$ (No. 14) \\
\hline$a, \AA$ & $12.310(1)$ & $15.146(8)$ & $31.342(4)$ & $11.360(3)$ \\
\hline$b, \AA$ & $12.310(1)$ & $15.146(8)$ & $31.342(4)$ & $17.131(6)$ \\
\hline$c, \AA$ & $17.308(2)$ & $21.338(10)$ & $22.000(6)$ & $18.952(6)$ \\
\hline$\alpha, \operatorname{deg}$ & 90 & 90 & 90 & 90 \\
\hline$\beta$, deg & 90 & 90 & 90 & $91.21(3)$ \\
\hline$\gamma$, deg & 90 & 120 & 120 & 90 \\
\hline$V, \AA^{3}$ & 2623 & 4239 & 18716 & 3687 \\
\hline$Z$ & 4 & 2 & 24 & 4 \\
\hline$\rho_{\text {calc, }}, \mathrm{Mg} \mathrm{m}^{-3}$ & 0.995 & 0.989 & 1.003 & 1.022 \\
\hline$\mu, \mathrm{mm}^{-1}$ & 0.274 & 0.233 & 0.207 & 0.299 \\
\hline $2 \theta$ range, deg & $8-55$ & $8-49$ & $8-50$ & $8-45$ \\
\hline no. of reflns measd & 2560 & 4752 & 7262 & 5197 \\
\hline no. of unique reflns & 1507 & 2342 & 7246 & 4883 \\
\hline no. of reflns used & 1506 & 2224 & 7244 & 4879 \\
\hline no. of restraints & 60 & 54 & 1177 & 522 \\
\hline$R_{2}^{a}$ (all data) & 0.153 & 0.195 & 0.168 & 0.090 \\
\hline$\left.R_{1}^{a} F>4 \sigma(F)\right)$ & 0.054 & 0.068 & 0.063 & 0.033 \\
\hline$g_{1}$ & 0.043 & 0.067 & 0.080 & 0.041 \\
\hline & 1.69 & 5.81 & 33.43 & 2.78 \\
\hline no. of refined params & 88 & 182 & 523 & 388 \\
\hline
\end{tabular}

${ }^{a} R_{2}=\left(\sum w\left(F_{0}^{2}-F_{\mathrm{c}}^{2}\right)^{2} / \sum w F_{0}^{4}\right)^{1 / 2} ; R_{1}=\sum \mid F_{0}-F_{\mathrm{d}} / \sum F_{0}$
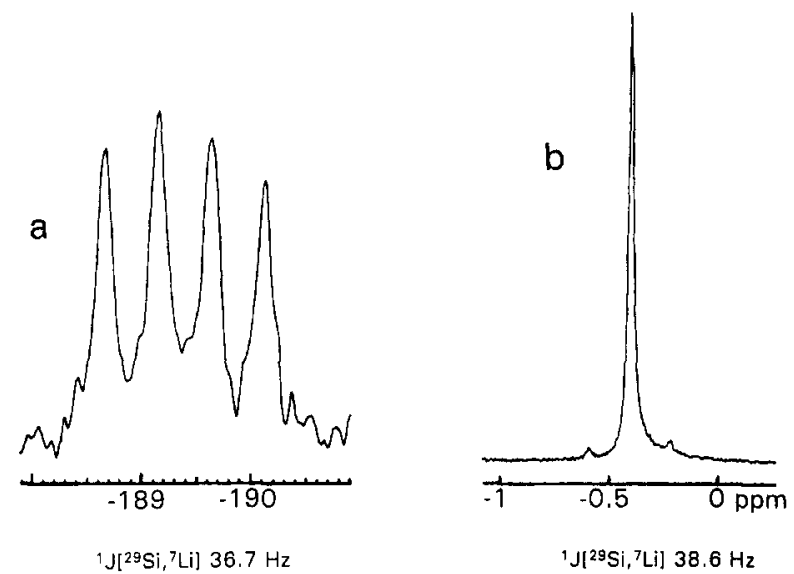

Figure 4. NMR spectra of 3: (a) ${ }^{29} \mathrm{Si}$ NMR showing the chemical shift $(\delta-189.4)$ of the central silicon a tom with the $\left.{ }^{1} J{ }^{29} \mathrm{Si},{ }^{7} \mathrm{Li}\right]$ coupling constant of $38.6 \mathrm{~Hz}$; (b) ${ }^{7} \mathrm{Li} \mathrm{NMR}$ at $-50^{\circ} \mathrm{C}$ depicting the chemical shift of 0.38 with the ${ }^{1} J\left[{ }^{29} \mathrm{Si},{ }^{7} \mathrm{Li}\right]$ coupling constant of $36.7 \mathrm{~Hz}$.

${ }^{1} J\left[{ }^{29} \mathrm{Si},{ }^{7} \mathrm{Li}\right]$ coupling constant for 3 is $38.6 \mathrm{~Hz}$ in the ${ }^{29} \mathrm{Si} \mathrm{NMR}$ spectrum at room temperature and $36.7 \mathrm{~Hz}$ in the ${ }^{7} \mathrm{Li}$ NMR spectrum at $-50^{\circ} \mathrm{C}$. Edlund, Buncel, et al..$^{19,20}$ detected a ${ }^{1} J\left[{ }^{29} \mathrm{Si},{ }^{7} \mathrm{Li}\right]$ coupling of $51 \mathrm{~Hz}$ for $\mathrm{PhMe}_{2} \mathrm{SiLi}$ in THF at -100 ${ }^{\circ} \mathrm{C}$. These values are of similar magnitude to the ${ }^{1} J\left[{ }^{19} \mathrm{~F},{ }^{7} \mathrm{Li}\right]$ couplings which we reported previously. ${ }^{21}$ The question of whether organolithium compounds are essentially ionic, covalent, or intermediate has been vigorously debated, ${ }^{22}$ and similar considerations clearly apply to silyllithium derivatives.

Crystal Structure of 4. Although the structure of hexakis(trimethylsilyl)disilane has been determined by other workers, ${ }^{11,12}$ the previously reported structure was relatively imprecise ${ }^{11}$ and was determined for a different modification (i.e. different space

(19) Edlund, U.; Lejon, T.; Venkatachalam, T. K.; Buncel, E. J. Am. Chem. Soc. 1985, 107, 6408.

(20) Edlund, U.; Lejon, T.; Pyykkő, P.; Venkatachalam, T. K.; Buncel, E. J. Am. Chem. Soc. 1987, 109, 5982.

(21) Stalke, D.; Klingebiel, U.; Sheldrick, G. M. J. Organomet. Chem. 1988, 344, 37.

(22) (a) Streitwieser, A., Jr.; Williams, J. E., Jr.; Alexandratos, S.; McKelvey, J. M. J. Am. Chem. Soc. 1976, 98, 4778, (b) Dill, J. D.; Schleyer, P. v. R.; Binkley, J. S.; Pople, J. A. J. Am. Chem. Soc. 1977, 99, 6159. (c) Graham, G. D.; Marynik, D. S.; Lipscomb, W. N. J. Am. Chem. Soc. 1980, 102, 4572. (d) Clark, T.; Rohde, C.; Schleyer, P. v. R. Organometallics 1983, 2, 1344. (e) Bachrach, S. M.; Streitwieser, A., Jr. J. Am. Chem. Soc. 1984, 106, 2283.
Table III. Atomic Coordinates $\left(\times 10^{4}\right)$ and Equivalent Isotropic Displacement Parameters $\left(\AA^{2} \times 10^{3}\right)$ for 1

\begin{tabular}{lllll}
\hline & \multicolumn{1}{c}{$x$} & \multicolumn{1}{c}{$y$} & \multicolumn{1}{c}{$z$} & $U(\text { eq })^{\circ}$ \\
\hline $\mathrm{Si}(2)$ & 7500 & 2500 & 2500 & $32.5(5)$ \\
$\mathrm{Si}(1)$ & $5943.6(6)$ & $2498.4(10)$ & $3282.4(4)$ & $37.3(5)$ \\
$\mathrm{C}(1)$ & $6106(3)$ & $3484(3)$ & $4105(2)$ & $50(2)$ \\
$\mathrm{C}(2)$ & $4717(3)$ & $2900(3)$ & $2703(2)$ & $48(2)$ \\
$\mathrm{C}(3)$ & $5708(3)$ & $1110(3)$ & $3698(2)$ & $50(2)$
\end{tabular}

e $U(e q)$ is defined as one-third of the trace of the orthogonalized $\mathbf{U}_{i j}$ tensor.

Table IV. Atomic Coordinates $\left(\times 10^{4}\right)$ and Equivalent Isotropic Displacement Parameters $\left(\AA^{2} \times 10^{3}\right)$ for 2

\begin{tabular}{lllcl}
\hline \multicolumn{1}{c}{$x$} & \multicolumn{1}{c}{$y$} & $z$ & $U(\mathrm{eq})^{a}$ \\
\hline $\mathrm{Li}(1)$ & 6667 & 3333 & $-61(6)$ & $50(4)$ \\
$\mathrm{O}(1)$ & $7277(3)$ & $2587(3)$ & $-437(2)$ & $73(2)$ \\
$\mathrm{C}(1)$ & $7812(17)$ & $2720(20)$ & $-1013(6)$ & $80(13)$ \\
$\mathrm{C}(2)$ & $8414(17)$ & $2239(21)$ & $-972(10)$ & $93(11)$ \\
$\mathrm{C}(3)$ & $8290(17)$ & $1856(20)$ & $-273(12)$ & $84(12)$ \\
$\mathrm{C}(4)$ & $7384(17)$ & $1850(17)$ & $-64(9)$ & $77(11)$ \\
$\mathrm{Si}(1)$ & 6667 & 3333 & $1192.8(9)$ & $40.4(7)$ \\
$\mathrm{Si}(2)$ & $5951.2(10)$ & $4209.7(10)$ & $1678.3(5)$ & $47.4(9)$ \\
$\mathrm{C}(5)$ & $4512(4)$ & $3497(5)$ & $1647(3)$ & $74(3)$ \\
$\mathrm{C}(6)$ & $6365(5)$ & $5453(4)$ & $1262(2)$ & $76(5)$ \\
$\mathrm{C}(7)$ & $6272(4)$ & $4562(4)$ & $2532(2)$ & $59(3)$ \\
$\mathrm{Si}(3)$ & 0 & 0 & $2611(3)$ & $42.4(10)$ \\
$\mathrm{Si}(4)$ & $1580(2)$ & $319(3)$ & $2246(2)$ & $83(2)$ \\
$\mathrm{C}(8)$ & $2592(13)$ & $1371(13)$ & $2734(13)$ & $117(8)$ \\
$\mathrm{C}(9)$ & $1776(9)$ & $747(13)$ & $1405(5)$ & $94(7)$ \\
$\mathrm{C}(10)$ & $1728(18)$ & $-837(12)$ & $2282(13)$ & $118(20)$ \\
$\mathrm{Si}(5)$ & 0 & 0 & $3708(2)$ & $71(2)$ \\
$\mathrm{C}(11)$ & $-1343(7)$ & $-611(11)$ & $4008(7)$ & $95(8)$
\end{tabular}

a $U(\mathrm{eq})$ is defined as one-third of the trace of the orthogonalized $\mathbf{U}_{U}$ tensor.

group and lattice solvent; Table II). The Si-Si bond (2.373 $\AA$ ) in 4 is on average $0.04 \AA$ longer than those in 1-3. The central $\mathrm{Si}(1)-\mathrm{Si}$ (5) bond is elongated by 0.06 to $2.390 \AA$ (Figure 5, Table I), and the $\mathrm{Me}_{3} \mathrm{Si}-\mathrm{Si}-\mathrm{Si}\left(\mathrm{SiMe}_{3}\right)_{3}$ angle across the central bond is $9^{\circ}$ larger $\left(113.8^{\circ}\right)$ than the $\mathrm{Me}_{3} \mathrm{Si}-\mathrm{Si}-\mathrm{SiMe}_{3}$ angle $\left(104.8^{\circ}\right)$, indicating appreciable steric strain in the disilane. The mean gauche $\mathrm{Si}-\mathrm{Si}-\mathrm{Si}-\mathrm{Si}$ torsion angles $\left(+77.2\right.$ and $\left.-42.8^{\circ}\right)$ differ substantially from the ideal values of $\pm 60^{\circ}$ expected for a strainfree eclipsed conformation.

Refinement of Severely Disordered Structures. All four structure refinements were complicated by disorder. Residual electron density around the 4-fold axis in the crystals of 1 could 
Table V. Atomic Coordinates $\left(\times 10^{4}\right)$ and Equivalent Isotropic Displacement Parameters $\left(\AA^{2} \times 10^{3}\right)$ for 3

\begin{tabular}{|c|c|c|c|c|}
\hline & $x$ & $y$ & $z$ & $U(\mathrm{eq})^{a}$ \\
\hline $\mathrm{Li}(1)$ & 6667 & 3333 & $5281(6)$ & $48(5)$ \\
\hline$O(1)$ & $6203.1(14)$ & $3486.3(13)$ & $5677.0(15)$ & $68(2)$ \\
\hline$C(1)$ & $5856(4)$ & $3227(3)$ & $6146(4)$ & $72(5)$ \\
\hline$C(2)$ & $5718(3)$ & $3566(3)$ & $6420(4)$ & $71(5)$ \\
\hline$C(3)$ & $6078(4)$ & 4068(3) & $6154(4)$ & $70(5)$ \\
\hline$C(4)$ & $6224(4)$ & $3949(3)$ & $5571(4)$ & $75(6)$ \\
\hline $\mathrm{Si}(1)$ & 6667 & 3333 & $4093.0(10)$ & $45.1(8)$ \\
\hline $\operatorname{Si}(2)$ & $7036.0(6)$ & $4104.0(6)$ & $3632.3(8)$ & $65.8(11)$ \\
\hline$C(5)$ & $6605(3)$ & $4364(3)$ & $3645(3)$ & $97(6)$ \\
\hline$C(6)$ & $7611(2)$ & $4558(2)$ & $4058(3)$ & $88(4)$ \\
\hline$C(7)$ & $7238(3)$ & $4153(3)$ & $2812(3)$ & $107(6)$ \\
\hline $\mathrm{Li}(2)$ & $8949(3)$ & $6782(3)$ & $407(4)$ & $60(6)$ \\
\hline$O(2)$ & $9664.9(13)$ & $7078.4(13)$ & $531(2)$ & $73(2)$ \\
\hline$C(8)$ & $9927(4)$ & $6825(4)$ & $385(7)$ & $81(3)$ \\
\hline$C(9)$ & $10422(3)$ & $7118(6)$ & $627(7)$ & $95(3)$ \\
\hline$C(10)$ & $10419(3)$ & $7509(6)$ & $1022(7)$ & $94(3)$ \\
\hline C(11) & $9920(4)$ & $7425(4)$ & $1009(5)$ & $81(4)$ \\
\hline$O(3)$ & $8889.8(12)$ & $7274.8(14)$ & $-42(2)$ & $81(2)$ \\
\hline$C(12)$ & $9297(3)$ & $7739(5)$ & $-237(9)$ & $71(3)$ \\
\hline$C(13)$ & $9107(4)$ & $7885(5)$ & $-757(7)$ & $75(4)$ \\
\hline$C(14)$ & $8561(3)$ & $7651(5)$ & $-640(7)$ & $85(4)$ \\
\hline$C(15)$ & $8441(2)$ & $7280(4)$ & $-174(6)$ & $88(3)$ \\
\hline$O(4)$ & $8871(6)$ & $6276(4)$ & $-169(6)$ & $83(7)$ \\
\hline$C(16)$ & $8966(7)$ & $6302(3)$ & $-805(7)$ & $107(8)$ \\
\hline$C(17)$ & $8721(6)$ & $5801(4)$ & $-1040(4)$ & $104(8)$ \\
\hline$C(18)$ & $8380(5)$ & $5486(4)$ & $-525(5)$ & $105(8)$ \\
\hline$C(19)$ & $8630(6)$ & $5771(5)$ & $26(4)$ & $84(7)$ \\
\hline $\mathrm{Si}(3)$ & $8380.9(5)$ & $6431.8(5)$ & $1394.7(6)$ & $45.0(7)$ \\
\hline $\mathrm{Si}(4)$ & $7528.2(5)$ & $6019.4(5)$ & $1262.2(7)$ & $54.3(7)$ \\
\hline$C(20)$ & $7128(2)$ & $5661(3)$ & $1923(3)$ & $83(3)$ \\
\hline$C(21)$ & $7345(2)$ & $5566(2)$ & $620(3)$ & $71(3)$ \\
\hline$C(22)$ & $7307(2)$ & $6460(2)$ & $1039(3)$ & $71(3)$ \\
\hline $\mathrm{Si}(5)$ & $8512.1(6)$ & $7074.1(6)$ & $2045.9(7)$ & $63.2(9)$ \\
\hline$C(23)$ & $8025(3)$ & $6969(3)$ & $2611(3)$ & $98(4)$ \\
\hline$C(24)$ & $8603(3)$ & $7614(2)$ & $1569(3)$ & $94(6)$ \\
\hline$C(25)$ & $9097(2)$ & $7300(3)$ & $2505(3)$ & $85(4)$ \\
\hline $\mathrm{Si}(6)$ & $8490.8(6)$ & $5904.4(6)$ & $2037.9(8)$ & $61.7(8)$ \\
\hline$C(26)$ & $9170(2)$ & $6126(3)$ & $2135(3)$ & $87(4)$ \\
\hline$C(27)$ & $8229(3)$ & $5810(3)$ & $2832(3)$ & $96(5)$ \\
\hline$C(28)$ & $8212(3)$ & $5264(2)$ & $1703(3)$ & $92(5)$ \\
\hline
\end{tabular}

a $U(e q)$ is defined as one-third of the trace of the orthogonalized $\mathrm{U}_{i j}$ tensor.

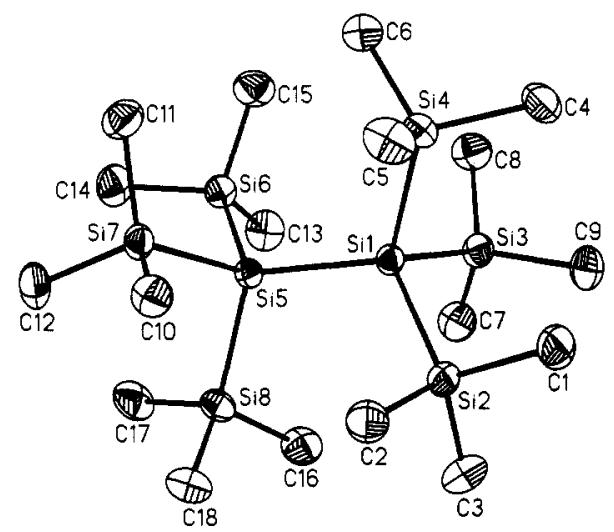

Figure 5. Structure of $\left(\mathrm{Me}_{3} \mathrm{Si}\right)_{3} \mathrm{SiSi}\left(\mathrm{SiMe}_{3}\right)_{3}(4)$ in the solid state. The uncoordinated THF molecule is omitted.

be identified as a disordered THF molecule, but it was impossible to distinguish between possible $\mathrm{O}$ and $\mathrm{C}$ atoms. Because of the 4-fold symmetry, we refined one five-membered ring of carbon atoms with occupancies set to 0.25 . All $1-2$ and $1-3$ distances were restrained to be respectively equal. To enable anisotropic refinement, we used rigid bond restraints ${ }^{23-25}$ together with weak restraints to make the corresponding $U_{i j}$ components of neigh-

(23) Rollet, J. S. In Crystallographic Computing, Ahmed, F. R., Hall, S. R., Huber, C. P., Eds.; Munksgaard: Copenhagen, 1970; pp 167-181.

(24) Hirshfeld, F. L. Acta Crystallogr. 1976, A32, 239.

(25) Trueblood, K. N.; Dunitz, J. P. Acta Crystallogr. 1983, B39, 120.
Table VI. Atomic Coordinates $\left(\times 10^{4}\right)$ and Equivalent Isotropic Displacement Parameters $\left(\AA^{2} \times 10^{3}\right)$ for 4

\begin{tabular}{|c|c|c|c|c|}
\hline & $x$ & $y$ & $z$ & $U(\text { eq })^{a}$ \\
\hline $\mathrm{Si}(1)$ & $8077.2(5)$ & $9016.3(3)$ & $1893.0(3)$ & $22.8(3)$ \\
\hline $\operatorname{Si}(2)$ & $10144.1(5)$ & $8807.9(4)$ & $1865.6(4)$ & $29.1(3)$ \\
\hline $\mathrm{Si}(3)$ & $7657.3(6)$ & 9998.1(4) & $1036.9(4)$ & $31.2(4)$ \\
\hline $\mathrm{Si}(4)$ & $7797.6(6)$ & $9645.6(4)$ & $2994.5(3)$ & $27.9(4)$ \\
\hline $\operatorname{Si}(5)$ & $6937.3(5)$ & $7852.9(3)$ & $1747.2(3)$ & $22.1(3)$ \\
\hline $\mathrm{Si}(6)$ & $4935.1(5)$ & $8093.6(4)$ & $1447.7(4)$ & $30.1(3)$ \\
\hline $\mathrm{Si}(7)$ & $6899.1(6)$ & $7035.5(4)$ & $2752.8(3)$ & $27.3(4)$ \\
\hline $\mathrm{Si}(8)$ & $7630.0(6)$ & $7038.6(4)$ & $835.1(3)$ & $30.7(4)$ \\
\hline$C(1)$ & $10922(2)$ & $9684(2)$ & $2239(2)$ & $45.5(14)$ \\
\hline$C(2)$ & $10688(2)$ & 7954(2) & $2392.7(15)$ & $41.4(14)$ \\
\hline$C(3)$ & $10683(2)$ & $8666(2)$ & $946.1(15)$ & $47.1(15)$ \\
\hline$C(4)$ & $8293(2)$ & $10691.4(15)$ & $2957.7(14)$ & $40(2)$ \\
\hline$C(5)$ & $8685(3)$ & $9153(2)$ & $3712.0(14)$ & $44(2)$ \\
\hline$C(6)$ & $6235(2)$ & $9676(2)$ & $3292.5(14)$ & $40.9(15)$ \\
\hline$C(7)$ & $7555(3)$ & $9646(2)$ & $100.4(14)$ & $45(2)$ \\
\hline$C(8)$ & $6235(2)$ & $10505(2)$ & $1233.4(15)$ & $44(2)$ \\
\hline $\mathrm{C}(9)$ & $8843(3)$ & $10761(2)$ & $1044(2)$ & $46(2)$ \\
\hline$C(10)$ & $8380(2)$ & $6873.0(15)$ & $3179.5(13)$ & $35.1(15)$ \\
\hline$C(11)$ & $5875(2)$ & $7407(2)$ & $3440.2(14)$ & $41(2)$ \\
\hline$C(12)$ & $6351(2)$ & $6042.7(14)$ & $2481(2)$ & $43(2)$ \\
\hline$C(13)$ & $4741(2)$ & $8412(2)$ & $505.8(14)$ & $46(2)$ \\
\hline$C(14)$ & $4018(2)$ & $7193(2)$ & $1564(2)$ & $46.5(14)$ \\
\hline$C(15)$ & $4240(2)$ & $8855(2)$ & $2005(2)$ & $46.2(14)$ \\
\hline$C(16)$ & $8108(3)$ & $7613(2)$ & 53.4(13) & $45(2)$ \\
\hline & $6446(3)$ & $6353(2)$ & $504(2)$ & $48(2)$ \\
\hline$C(18)$ & $8912(2)$ & $6425(2)$ & $1136.8(4)$ & $43(2)$ \\
\hline
\end{tabular}

$c U(e q)$ is defined as one-third of the trace of the orthogonalized $U_{l j}$ tensor.

boring atoms similar. There were similar problems with disordered THF on a general position in structure 4. Here we refined three five-membered rings of carbon atoms with occupancies of $1 / 3$ and applied the above restraints. In structures 2 and 3 , the coordinated THF molecules were disordered. The carbon atoms occupy two and, in one case, even three positions. Here we applied similarity restraints for all chemically equivalent $1-2$ and 1-3 distances. For the anisotropic displacement parameters we used only the rigid bond restraints. The tetrakis(trimethylsilyl)silane in structure 2 lies on a position of crystallographic $D_{3}$ symmetry but has only 3 -fold molecular symmetry, so the central atom (Si(3)) lies on the 3 -fold axis close to the $D_{3}$ position at $0,0,1 / 4$, and $\mathrm{Si}(5)$ also lies on the 3 -fold axis, but the molecule is disordered with respect to the 2 -fold axes. To stabilize the refinement we used similarity restraints for the 1-2 and 1-3 Si-Si distances and for the 1-2 Si-C distances. We also tried refinement in the lower symmetry space group $P \overline{3}$, but the same disorder appeared and the refinement was less stable.

In our experience, the careful application of chemically meaningful restraints to disordered groups and solvent considerably improves the precision of the rest of the structure. The estimated standard deviations are much lower and at the same time the residual electron density is more informative, because residual features cannot be simply "mopped up" by the refinement of an excessive number of arbitrary parameters. ${ }^{26}$ This is underlined by a comparison of our structure determination of 4 to that quoted above. ${ }^{11}$

Conclusion. On the one hand, the relatively small $\mathrm{Si}-\mathrm{Si}-\mathrm{Si}$ angles in $\mathbf{2}$ and $\mathbf{3}$ support the ionic character of the $\mathrm{Si}-\mathrm{Li}$ bond, and on the other hand, the ${ }^{1} J[\mathrm{Si}, \mathrm{Li}]$ coupling of 3 requires at least some covalency. In the disilane 4 steric factors also appear to be important.

\section{Experimental Section}

All manipulations were performed under an inert atmosphere of dry argon gas with Schlenk techniques or in an argon glovebox. The toluene, $n$-hexane, and THF solvents were dried over $\mathrm{Na} / \mathrm{K}$ alloy and distilled prior to use.

(26) Sheldrick, G. M. SHELXL-92 program for crystal structure refinement. University of Göttingen, 1992. 
NMR spectra were obtained with a Bruker MSL 400 instrument. All NMR spectra were recorded in toluene- $d_{8}$ or benzene- $d_{6}$ with SiMe 4 or $\mathrm{LiCl}$ external reference.

Warning! 3 is extremely pyrophoric and should be handled in small amounts under dry inert gas atmosphere.

(Me3 $\mathrm{Si}_{\mathbf{S}} \mathrm{Si}$ (1). Tetrakis(trimethysilyl)silane was prepared according to the published procedure of Gilman and Smith. ${ }^{1}$

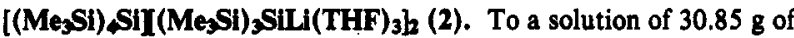
(Me $\left.{ }_{3} \mathrm{Si}\right)_{4} \mathrm{Si}(96.4 \mathrm{mmol})$ in $400 \mathrm{~mL}$ of THF was added a slight excess of $\mathrm{MeLi}(69 \mathrm{~mL} ; 108.8 \mathrm{mmol})$ in diethyl ether over a period of $2 \mathrm{~h}$. First a pale yellow and later an orange solution was obtained. After $1 \mathrm{~d}$ of stirring at room temperature, the THF was condensed of and the yellow precipitate redissolved in $60 \mathrm{~mL}$ of diethyl ether. The product was obtained by crystallization from that solution at $-18^{\circ} \mathrm{C}$ as a white powder. Yield: $25.5 \mathrm{~g}(63 \%)$. X-ray-suitable crystals have also been grown from diethyl ether solution. NMR: ${ }^{1} \mathrm{H}\left(\mathrm{C}_{7} \mathrm{D}_{8}\right) \delta 0.242 \quad\left[\left(\mathrm{Me}_{3} \mathrm{Si}\right)_{3} \mathrm{SiLi}\right], 0.258$ [( $\left(\mathrm{Me}_{3} \mathrm{Si}\right) \mathrm{Si}$ ] (ratio 2:1); ${ }^{29} \mathrm{Si}\left(\mathrm{C}_{7} \mathrm{H}_{8} / \mathrm{C}_{6} \mathrm{D}_{6}\right) \delta-5.21$ [(Me $\left.\left.{ }_{3} \mathrm{Si}\right)_{3} \mathrm{SiLi}\right],-9.81$ [( $\left.\mathrm{Me}_{3} \mathrm{Si}\right)_{4} \mathrm{Si}$ ], -135.48 [ $\left(\mathrm{Me}_{3} \mathrm{Si}\right)_{4} \mathrm{Si}$ ], -189.4 [( $\left(\mathrm{Me}_{3} \mathrm{Si}\right)_{3} \mathrm{SiLi}$ ].

$\left(\mathrm{Me}_{3} \mathrm{Si}_{3} \mathrm{SiLi}(\mathrm{THF})_{3}\right.$ (3). $100 \mathrm{~mL}$ of $\mathrm{MeLi}(160 \mathrm{mmol})$ in diethyl ether was added over a period of $3 \mathrm{~h}$ to a solution of $50 \mathrm{~g}$ of $\left(\mathrm{Me}_{3} \mathrm{Si}\right)_{4} \mathrm{Si}$ (156.3 mmol) in $800 \mathrm{~mL}$ of THF. Approximately a quarter of the solvent was removed in vacuum, and the reaction mixture was stirred for $4 \mathrm{~d}$ at room temperature. The solvent was totally removed and the solid precipitate redissolved in diethyl ether. The product was crystallized from diethyl ether at $-18^{\circ} \mathrm{C}$ and recrystallized twice from $n$-hexane. Yield: $32.33 \mathrm{~g}(44 \%)$. X-ray-suitable crystals have also been grown from $n$-hexane. (Me $\mathrm{Mi}_{3} \mathrm{SiLi}(\mathrm{THF})_{3}$ was isolated as a white powder. NMR: ${ }^{1} \mathrm{H}\left(\mathrm{C}_{7} \mathrm{D}_{8}\right) \delta 0.242\left[\mathrm{Me}_{3} \mathrm{Si}\right], 1.458,3.560$ [THF]; ${ }^{29} \mathrm{Si}\left(\mathrm{C}_{7} \mathrm{H}_{8} /\right.$ $\left.\mathrm{C}_{6} \mathrm{D}_{6}\right) \delta-5.21\left[\left(\mathrm{Me}_{3} \mathrm{Si}\right)_{3} \mathrm{Si}\right],-189.4\left[\left(\mathrm{Me}_{3} \mathrm{Si}\right)_{3} \mathrm{Si}\right],{ }^{1} \mathrm{~J}[\mathrm{Si}, \mathrm{Li}]=38.6 \mathrm{~Hz}$; ${ }^{7} \mathrm{Li}\left(\mathrm{C}_{7} \mathrm{D}_{8}, T=-50^{\circ} \mathrm{C}\right) \delta 0.38 ;{ }^{1} J[\mathrm{Si}, \mathrm{Li}]=36.7 \mathrm{~Hz}$.

(Me $\mathrm{Si}_{3} \mathrm{SISI}_{3}\left(\mathrm{SiMe}_{3}\right)_{3}$ (4). To $0.73 \mathrm{~g}$ of $\mathrm{PbCl}_{2}(2.62 \mathrm{mmol}$ ) in $20 \mathrm{~mL}$ of toluene was added a solution of $2.46 \mathrm{~g}(5.24 \mathrm{mmol})$ of $\left(\mathrm{Me}_{3} \mathrm{Si}\right)_{3} \mathrm{SiLi}$ -

(27) Sheldrick, G. M. Acta Crystallogr. 1990, A46, 467.
$(\mathrm{THF})_{3}$ in $20 \mathrm{~mL}$ of toluene over $30 \mathrm{~min}$ at $-78^{\circ} \mathrm{C}$. The resulting solution was stirred at $-78^{\circ} \mathrm{C}$ for $7 \mathrm{~h}$, at $0^{\circ} \mathrm{C}$ for $10 \mathrm{~h}$, and finally at room temperature for $7 \mathrm{~h}$. The black precipitate of elemental lead was filtered off, $2 \mathrm{~mL}$ of THF was added to the clear solution, and after $10 \mathrm{~d}$ at -30 ${ }^{\circ} \mathrm{C}$ crystals, identified as 4 , were obtained. Yield: $0.930 \mathrm{~g}$ (71.8\%). NMR: ${ }^{1} \mathrm{H}\left(\mathrm{C}_{6} \mathrm{D}_{6}\right) \delta 0.361 ;{ }^{13} \mathrm{C}\left(\mathrm{C}_{6} \mathrm{D}_{6}\right): \delta 4.92 ;{ }^{29} \mathrm{Si}\left(\mathrm{C}_{6} \mathrm{D}_{6}\right) ; \delta-9.51$ [( $\left.\left(\mathrm{Me}_{3} \mathrm{Si}\right)\right],-130.04\left[\left(\mathrm{Me}_{3} \mathrm{Si}\right)_{3} \mathrm{Si}\right]$. Mass spectrum [m/z (\%)]: EI 494 $\left(\mathrm{M}^{+}, 3\right)$; FI $494\left(\mathrm{M}^{+}, 100\right)$.

\section{$X$-ray Structure Determination of 1 to 4}

Crystal data of the four structures are presented in Table II. All data were collected at $-120^{\circ} \mathrm{C}$ on a Stoe-Siemens-AED with graphitemonochromated Mo $\mathrm{K} \alpha(\lambda=0.71073 \AA)$ radiation.

The structures were solved by direct methods. ${ }^{27}$ All non-hydrogen atoms were refined anisotropically. ${ }^{26}$ For the hydrogen atoms, the riding model was used; the structures were refined against $F^{2}$ with a weighting scheme of $w^{-1}=\sigma^{2}\left(F_{0}{ }^{2}\right)+\left(g_{1} P\right)^{2}+g_{2} P$ with $P=\left(F_{0}{ }^{2}+2 F_{\mathrm{c}}{ }^{2}\right) / 3$. Refinement of an inversion twin parameter ${ }^{28}[x=0.04(19)$ where $x=$ 0 for the correct absolute structure and +1 for the inverted structure] confirmed the absolute structure of 3 . The atomic coordinates of structures $1-4$ are given in Tables III-VI.

Acknowledgment. G.M.S. wishes to thank the LeibnizProgramm of the Deutschen Forschungsgemeinschaft and D.S. wishes to thank the Deutsche Forschungsgemeinschaft for financial support. We are grateful to Wolfgang Zolke for recording the NMR spectra and to Dr. F. Koch (Riedel-de Haën, Seelze, Germany) for providing the perfluorinated polyethers used for crystal mounting.

Supplementary Material Available: Tables giving crystal data and details of the structure determination, atom coordinates, bond lengths, bond angles, anisotropic thermal parameters, and hydrogen atom locations (23 pages). Ordering information is given on any current masthead page.

(28) Flack, H. D. Acta Crystallogr. 1983, A39, 876. 